\title{
Mycophagous Drosophilidae (Diptera) guild and their hosts in the Brazilian Amazon
}

\author{
Rosângela Santa-Brígida ${ }^{1,6}$; Felipe Wartchow ${ }^{2}$; Priscila Sanjuan Medeiros ${ }^{3}$; Marco Silva Gottschalk ${ }^{4}$; \\ Marlúcia Bonifácio Martins ${ }^{5}$ \& Claudio José Barros de Carvalho ${ }^{1,7}$
}

1 Universidade Federal do Paraná (UFPR), Departamento de Zoologia (DZO0), Programa de Pós-Graduação em Entomologia. Curitiba, PR, Brasil.

${ }^{2}$ Universidade Federal da Paraíba (UFPB), Centro de Ciências Exatas e da Natureza (CCEN), Departamento de Sistemática e Ecologia (DSE). João Pessoa, PB, Brasil. ORCID: http://orcid.org/0000-0003-4930-565X. E-mail: fwartchow@yahoo.com.br

3 Instituto Tecnológico Vale, Desenvolvimento Sustentável. Belém, PA, Brasil. ORCID: http://orcid.org/0000-0002-5001-9573. E-mail: priscilasanjuanbio@yaho0.com.br

${ }^{4}$ Universidade Federal de Pelotas (UFPEL), Instituto de Biologia (IB), Departamento de Ecologia, Zoologia e Genética (DEZG). Capão do Leão, RS, Brasil. ORCID: http://orcid.org/0000-0002-9453-4331. E-mail: gotts007@yahoo.com

${ }^{5}$ Museu Paraense Emílio Goeldi (MPEG), Campus de Pesquisa, Departamento de Zoologia. Belém, PA, Brasil. ORCID: http://orcid.org/0000-0003-4171-909X. E-mail: marlucia@museu-goeldi.br

${ }^{6}$ ORCID: http://orcid.org/0000-0003-0072-225X. E-mail: rosangela_brigida@yahoo.com.br (corresponding author)

7 ORCID: http://orcid.org/0000-0002-3533-6853. E-mail: cjbcarva@ufpr.br

\begin{abstract}
The composition and potential hosts of mycophagous Drosophilidae from a section of the Brazilian Amazon forest in the Caxiuanã National forest were investigated. Sampling was performed in three different periods at long the wet season (January (beginning) and July (end) 2013 and May (middle) 2014). The samples were collected from existing trails by actively searching for fungal fruiting bodies where Drosophilidae were present. We present composition and richness analysis over two years of sampling sampling Drosophilidae and Fungi. We evaluate sampling completeness using asymptotic species richness estimators. Out of 159 fruiting body samples and 64 fungal species, 5,124 drosophilids belonging to 55 species and 5 genera were collected. The mycophagous Drosophilidae richness values estimated by Jackknife 1 and Bootstrap were 69 and 61, respectively. The estimated fly richness correlated positively with fungal richness and abundance. Among the Drosophilidae species identified in this study, approximately $5 \%$ represent new occurrences for Brazil and $56 \%$ represent new species. Four genera belonging to the Zygothrica genus group are found in the Amazon region, and these genera represent $80 \%$ of the fungus-associated fauna known to date for the tropics. In conclusion, our results show that the fungal richness and abundance were the factors that determined the high diversity of mycophagous Drosophilidae.
\end{abstract}

Key-Words. Agaricales; Basidiomycota; Drosophila; Fungal composition; Hirtodrosophila; Insects; Mycodrosophila; Polyporaceae; Species richness; Zygothrica.

\section{INTRODUCTION}

Community ecology aims to understand species abundance and distribution, which depend on biotic and abiotic variables (Diamond, 1986). One of the main challenges in the study of communities is the appropriate delimitation of a community, which is necessary to understand the processes that condition a given group of organisms. One way of facilitating the understanding of community organization processes is to focus on a group of species. One way to select a reference group is to focus on the guilds. Guilds are defined as groups of organisms that use same resource category (Root, 1967; Fauth et al., 1996; Magurran, 2011), and the species can or not be phylogenetically related (Magurran, 2011). Considering these concepts, mycophagous Drosophilidae are phylogenetically related species that can be classified as a guild, considering that they are organisms are strongly associated based on the use of the same group of resources.

Sturtevant (1921) was the first to register that many species of Drosophilidae used fungi for reproduction. Since then, other studies have described in more detail species that use fungi not only to reproduce but also to feed adults, while they eat microorganisms (yeasts or bacteria) present in the fruiting bodies (Courtney et al., 1990; Powell, 1997), larvae feed on the hyphae and microorganisms (Kimura, 1976; Martin, 1979; Lacy, 1984; Hosaka \& Uno, 2012). In other species like Hirtodrosophila polypori (Malloch) the males use the hosts to court (Parsons, 1977). 
In the Neotropics, few studies have widely and systematically addressed Drosophilidae mycophagy. The taxonomy of this group, however, is quite well understood than other drosophilids (Sturtevant, 1920; Hendel, 1936; Frota-Pessoa, 1945, 1951; Cordeiro, 1952; Burla, 1956; Brncic, 1957; Wheeler \& Takada, 1963; Mourão et al., 1965, 1967; Grimaldi, 1987; Junges et al., 2016). The descriptions of Hirtodrosophila Duda, Mycodrosophila Oldenberg and Zygothrica Wiedemann species were, most of them from specimens in entomological collections. Heed (1957) and Grimaldi (1987) studied ecological aspects of feeding, breeding and mating. In Brazil, mycophagous species have been identified in the Cerrado (Roque et al., 2006; Roque \& Tidon, 2008), Atlantic Rainforest (Gottschalk et al., 2009) and Pampas biomes (Valer et al., 2016). Among these studies, Gottschalk et al. (2009) and Valer et al. (2016) focused more specifically on fungus hosts of flies. These studies contributed to our understanding of the mycophagous fauna in these regions and the natural history of these groups.

The mycophagy probably evolved from detritivory in drosophilids and may have appeared independently in different lineages within the group (Throckmorton, 1975; Powell, 1997). Grimaldi (1990) proposed that mycophagy may represent a synapomorphy for the Zygothrica genus group clade (Hirtodrosophila + Mycodrosophila + Zygothrica + Paraliodrosophila Duda + Paramycodrosophila) but there are other mycophagous groups that derived this trait independently like some species of Drosophila, Leucophenga and Scaptomyza (Courtney et al., 1990).

The data published on the natural history of mycophagous drosophilids are mostly fragmented. These works in general approach the mycophagy of groups of insects or Dipetra that use the fruiting bodies for its development (Burla \& Bächli, 1968; Buxton, 1954, 1960; Ackerman \& Shenefelt, 1973; Jaenike, 1978; Shorrocks \& Charlesworth, 1980; Coutin, 1982; Worthen, 1989; Wertheim et al., 2000; Yamashita \& Hijii, 2003; Takahashi et al., 2005; Kadowaki, 2010) or specifically related to the genus Drosophila (Bock \& Parsons, 1978; Shorrocks \& Charlesworth, 1982; Lacy, 1984; Grimaldi et al., 1992; Heard, 1998). Courtney et al. (1990) studied mycophagous Drosophilidae ecology and classified the relevant species based on the type of feeding, grouping species that feed solely on fungi as strictly mycophagous and those that can feed on fungi or other resources as facultative mycophagous. Initially, mycophagous Drosophilidae were considered to be generalists with respect to their feeding and reproductive habits (Lacy, 1984; Hanski, 1989; Courtney et al., 1990). However, a recent study suggested that some species of Hirtodrosophila, Leucophenga and Zygothrica are specialists with respect to reproduction (Valer et al., 2016).

The Brazilian Drosophilidae fauna is extremely rich and widely distributed among all biomes (Val et al., 1981). However, this group is poorly studied in some of the country's Northern and Northeastern states and regions. Even in states where the group is well studied, species that inhabit substrates other than fruits represent a knowledge gap, given that most sampling approaches utilize fermenting banana as the attractant (Gottschalk et al., 2008). Mycophagous Drosophilidae can be attracted by commercial mushroom bait, which is a successful technique that is used in community studies in temperate regions (Shorrocks \& Charlesworth, 1980). By contrast, data on tropical mycophagous Drosophilidae guild are from samples collected from naturally occurring fungi in the areas of Cerrado, the Atlantic Rainforest and Pampas (Roque et al., 2006; Roque \& Tidon, 2008; Gottschalk et al., 2009).

We investigated the composition and richness of the mycophagous Drosophilidae guild and their potential hosts in a region of the Brazilian Amazon forest.

\section{MATERIALS AND METHODS}

\section{Study area}

Sampling was performed in the Caxiuanã National Forest Reserve in the eastern Amazon ( $\left.01^{\circ} 43^{\prime} \mathrm{S}, 51^{\circ} 27^{\prime} \mathrm{W}\right)$, in a portion of the Amazon biome located in the municipalities of Melgaço and Portel in Pará State, Brazil. Caxiuanã National Forest Reserve contains approximately 300,000 ha and comprises $80 \%$ dense ombrophilous forest and $20 \%$ patches of savanna, Capoeira (low vegetation), Igapó (seasonally flooded vegetation), Várzea (floodplain) and vast aquatic vegetation (Lisboa et al., 2007). According to the Köppen classification, the climate is hot and humid, with climate subtype 'Am' (tropical monsoon climate). The region experiences a short dry season and recurrent rain throughout the year (Oliveira et al., 2008). Seasonality is defined by the amount of rain, with a lower rainfall index from July to November $(27.5 \%$ rain) and a wet season from December to June $(72.5 \%$ rain) (Oliveira et al., 2008). The mean annual temperature is $26^{\circ} \mathrm{C}$, with little variability (minimum of $22^{\circ} \mathrm{C}$ and maximum of $32^{\circ} \mathrm{C}$ ) (Costa et al., 2009).

\section{Sampling method and identification}

Three Caxiuanã National Forest Reserve sampling expeditions were performed during the wet season, with two expeditions in 2013 (January and July) and one expedition in May 2014. Samples were collected by actively searching existing trails for fungal fruiting bodies with the presence of Drosophilidae for a total of 18 days, with six days per expedition. In this study we defined a sample corresponding to the conjunct of fruit body of one fungal species (Fig. 3). A total of $27 \mathrm{~km}$ (A total of $9 \mathrm{~km}$ field of trails was surveyed in each field trip, totaling $18 \mathrm{hs}$ of sampling per field trip) of trails was surveyed.

Sampling was performed between 8 am and 11 am, when Drosophilidae are more active (Pavan et al., 1950). Flies on the fungal surface were collected using a mechanical aspirator or entomological nets and stored in labeled tubes containing absolute ethanol. Following the collection of the adult flies hovering over the fungi, the exposed fruiting bodies and the fungal substrate were 
photographed, and fungal specimens were collected for identification.

Flies were identified based on external morphology and when possible, male and female terminalia, based on the literature (Hendel, 1936; Frota-Pessoa, 1945; Burla, 1956; Wheeler \& Takada, 1963, 1971; Grimaldi, 1987, 1990; Vilela \& Bächli, 1990, 2004, 2007). Dissections of terminalia were performed following Wheller \& Kambysellis (1966), as modified by Kaneshiro (1969). The material is housed at the Entomological Collection of the Museu Paraense Emílio Goeldi (MPEG) Entomological Collection in the city of Belém in Pará State, Brazil, and at the Padre Jesus Santiago Moure Entomological Collection of the Zoology Department of the Federal University of Paraná (Departamento de Zoologia, Universidade Federal do Paraná - DZUP) in the city of Curitiba in Paraná State, Brazil.

Fungal fruiting body sampling was performed according to the documentation and preservation methods cited by Fidalgo \& Bononi (1989). Macroscopic and microscopic analyses were performed, and microstructure analysis was accomplished using sample slices mounted between a slide and a slide cover with a solution of $3 \% \mathrm{KOH}, 1 \%$ phloxine and Melzer's reagent (Teixeira, 1995). The identification and/or confirmation of species were performed based on the specialized literature (e.g., Ryvarden \& Johansen, 1980; Furtado, 1981; Ryvarden, 1991, 2004). The mycological nomenclature and classification follow Kirk et al. (2008).

\section{Assemblage characterization}

A Whittaker graphical representation showing absolute species abundance ( $\log N$ ) was used to display guild dominance patterns (Krebs, 1999). The following four models were tested to identify the model that best describes the abundance distribution data: (1) Geometric Series: assumes that each species in the community utilizes a fraction of the resource according to its dominance (McGill, 2011); (2) Logarithmic Series (Log-series): the model with the most uniform abundance distribution, in which resources are randomly and sequentially shared among niches (Magurran, 2011); (3) Broken stick: a model without a predominant species, based on the random and simultaneous sharing of resources among species (Pielou, 1975); and (4 Log-normal: a model that describes most of the species abundance distribution within the community and similar to the logarithmic series model, is associated with the community equilibrium, with small proportions of rare species (Sugihara, 1980). Modeling was performed using Past 3.05 (Hammer et al., 2001). To choose of the model that better adjusted the distribution, was considered as parameter the significance. Models that were significant or presented high values were considered models that did not good fit.

Species accumulation curves for Drosophilidae (observed species richness, Sobs) and Jackknife 1 and Bootstrap estimation curves were built (Smith \& van Belle, 1984). These methods account for sampling size
Table 1. Drosophilidae abundance for $I=1^{\text {st }}$ expedition (January 2013), $\|=2^{\text {nd }}$ expedition (July 2013) and $I I I=3^{\text {rd }}$ expedition (May 2014) $\mathrm{F}=$ Frequency. Morphospecies are referenced according to listings from the DZUP and MPEG entomological collections.

\begin{tabular}{|c|c|c|c|c|c|c|}
\hline Genus & Species/Morphospecies & I & II & III & $\mathbf{F}(\%)$ & Total \\
\hline Drosophila & D. atrata Burla \& Pavan & & & 4 & 30 & 4 \\
\hline Drosophila & (SB13005) & 34 & 1 & & 60 & 35 \\
\hline Drosophila & (SB13009) & 51 & 160 & 6 & 100 & 217 \\
\hline Drosophila & (SB14051) & & & 11 & 30 & 11 \\
\hline Hirtodrosophila & H. clypeata (Wheeler) & 45 & 61 & 1 & 100 & 107 \\
\hline Hirtodrosophila & H. minuscula Vilela \& Bächli & & & 12 & 30 & 12 \\
\hline Hirtodrosophila & H. morgani Mourão, Gallo \& Bicudo) & 6 & & 3 & 60 & 9 \\
\hline Hirtodrosophila & H. subflavohalterata (Burla, 1956) & 19 & & 1 & 60 & 20 \\
\hline Hirtodrosophila & (SB13010) & 88 & 3 & 52 & 100 & 143 \\
\hline Hirtodrosophila & (SB13011) & 419 & 17 & 327 & 100 & 763 \\
\hline Hirtodrosophila & (SB14003) & 5 & & 15 & 60 & 20 \\
\hline Hirtodrosophila & (SB14004) & 2 & & & 30 & 2 \\
\hline Hirtodrosophila & (SB14005) & 1 & & & 30 & 1 \\
\hline Hirtodrosophila & (SB14006) & 1 & & & 30 & 1 \\
\hline Hirtodrosophila & (SB14007) & 5 & 2 & 64 & 100 & 71 \\
\hline Hirtodrosophila & (SB14009) & 1 & & & 30 & 1 \\
\hline Hirtodrosophila & (SB14010) & 1 & & & 30 & 1 \\
\hline Hirtodrosophila & (SB14011) & 1 & & 23 & 60 & 24 \\
\hline Hirtodrosophila & (SB14033) & 2 & & & 30 & 2 \\
\hline Hirtodrosophila & (SB14034) & 22 & & & 60 & 22 \\
\hline Hirtodrosophila & (SB14035) & & & 136 & 30 & 136 \\
\hline Hirtodrosophila & (SB14041) & & & 9 & 30 & 9 \\
\hline Hirtodrosophila & (SB14049) & & & 1 & 30 & 1 \\
\hline Mycodrosophila & M. brunnescens Wheeler \& Takada & 2 & & & 30 & 2 \\
\hline Mycodrosophila & M. elegans Wheeler \& Takada & 12 & 2 & 23 & 100 & 37 \\
\hline Mycodrosophila & M. neoprojectans Wheeler \& Takada & 162 & & 105 & 60 & 267 \\
\hline Mycodrosophila & M. projectans (Sturtevant) & 81 & 7 & 107 & 100 & 195 \\
\hline Mycodrosophila & M. pseudoprojectans Wheeler \& Takada & 84 & 2 & 52 & 100 & 138 \\
\hline Paraliodrosophila & P. antennata Wheeler & 137 & 17 & 8 & 100 & 162 \\
\hline Zygothrica & Z. atriangula Duda & & 1 & 288 & 60 & 289 \\
\hline Zygothrica & Z. caudata Hendel & & & 1 & 30 & 1 \\
\hline Zygothrica & Z. dimidiata Duda & & & 1 & 30 & 1 \\
\hline Zygothrica & Z. joeyesco Grimaldi & & & 1 & 30 & 1 \\
\hline Zygothrica & Z. microeristes Grimaldi & & 5 & 269 & 60 & 274 \\
\hline Zygothrica & Z. orbitalis (Sturtevant) & & 140 & & 30 & 140 \\
\hline Zygothrica & Z. poeyi (Sturtevant) & 165 & 4 & 105 & 100 & 274 \\
\hline Zygothrica & Z.prodispar Duda & & & 1 & 30 & 1 \\
\hline Zygothrica & Z. radialis Grimaldi & & & 30 & 30 & 30 \\
\hline Zygothrica & Z. subcandens Burla & & & 4 & 30 & 4 \\
\hline Zygothrica & Z. virgatalba Burla & 10 & & 165 & 60 & 175 \\
\hline Zygothrica & Z. virgatinigra Burla & & & 18 & 30 & 18 \\
\hline Zygothrica & Z. zygia Grimaldi & & & 224 & 30 & 224 \\
\hline Zygothrica & (SB14002) & 1 & & 2 & 60 & 3 \\
\hline Zygothrica & (SB14003) & & & 154 & 30 & 154 \\
\hline Zygothrica & (SB14016) & & & 243 & 30 & 243 \\
\hline Zygothrica & (SB14025) & & & 104 & 30 & 104 \\
\hline Zygothrica & (SB14028) & & & 1 & 30 & 1 \\
\hline Zygothrica & (SB14037) & & & 34 & 30 & 34 \\
\hline Zygothrica & (SB14038) & & & 283 & 30 & 283 \\
\hline Zygothrica & (SB14042) & & & 78 & 30 & 78 \\
\hline Zygothrica & (SB14043) & & & 3 & 30 & 3 \\
\hline Zygothrica & (SB14047) & & & 1 & 30 & 1 \\
\hline Zygothrica & (SB14052) & & & 1 & 30 & 1 \\
\hline Zygothrica & (SB14022) & & & 8 & 30 & 8 \\
\hline \multirow[t]{2}{*}{ Zygothrica } & (SB14017) & & & 366 & 30 & 366 \\
\hline & & 1357 & & 3345 & & 5124 \\
\hline
\end{tabular}


Table 2. Fungal species and morphospecies recorded at Caxiuanã FLONA showing families, the number of collected fruiting bodies (samples $(S))$, Drosophilidae abundance (DA) and number of Drosophilidae species (RD) collected from each fungal species.

\begin{tabular}{|c|c|c|c|c|c|c|}
\hline Order & Family & Genus & Species/Morphospecies & $S$ & DA & RD \\
\hline \multirow[t]{25}{*}{ Agaricales } & Agaricaceae & Leucocoprinus & L. cretaceous (Bull.) Locq & 1 & 20 & 2 \\
\hline & Marasmiaceae & Crinipellis & sp. & 1 & 1 & 1 \\
\hline & & Lactocollybia & sp. & 3 & 216 & 10 \\
\hline & & Marasmius & sp. & 2 & 144 & 4 \\
\hline & & Nothopanus & sp. & 1 & 1 & 1 \\
\hline & Mycenaceae & Heimiomyces & sp. & 1 & 4 & 2 \\
\hline & Omphalotaceae & Gymnopus & sp. 1 & 6 & 16 & 5 \\
\hline & & Gymnopus & sp. 2 & 1 & 20 & 5 \\
\hline & & Gymnopus & sp. 3 & 3 & 33 & 4 \\
\hline & & Hydropus & sp. & 1 & 7 & 2 \\
\hline & & Marasmiellus & M. cf. volvatus & 3 & 20 & 6 \\
\hline & & Marasmiellus & sp. 4 & 1 & 139 & 16 \\
\hline & Physalacriaceae & Oudemansiella & sp. & 1 & 17 & 4 \\
\hline & Pleurotaceae & Hoehnbuehelia & sp. & 2 & 2 & 2 \\
\hline & & Pleurotus & P. cf. djamor & 1 & 8 & 4 \\
\hline & & Pleurotus & sp. & 1 & 1 & 1 \\
\hline & Strophariaceae & & Agaricales sp. 1 & 1 & 36 & 6 \\
\hline & & Gymnopilus & sp. 1 & 1 & 22 & 5 \\
\hline & Tricholomataceae & & Agaricales sp. 4 & 1 & 121 & 7 \\
\hline & & Collybia & C. aurea (Beeli) Pegler & 2 & 198 & 16 \\
\hline & & Filoboletus & F. gracilis (Klotzch ex berk.) & 1 & 4 & 2 \\
\hline & & Hemimycena & sp. 1 & 3 & 27 & 5 \\
\hline & & Hemimycena & sp. 2 & 1 & 41 & 3 \\
\hline & & Hemimycena & sp. 13 & 2 & 9 & 2 \\
\hline & & Hygrocybe & H. occidentalis (Dennis) Pegler & 1 & 2 & 1 \\
\hline Agaricales & & & sp. 2 & 1 & 6 & 1 \\
\hline Agaricales & & & sp. 5 & 3 & 5 & 3 \\
\hline Agaricales & & & sp. 6 & 1 & 1 & 1 \\
\hline Agaricales & & & sp. 10 & 2 & 185 & 12 \\
\hline Auriculariales & Auriculariaceae & Auricularia & A. mesenterica (Dicks.) Pers. & 1 & 4 & 4 \\
\hline Cantharellales & Hydnaceae & & sp. 1 & 1 & 57 & 9 \\
\hline Geastrales & Geastraceae & Geastrum & sp. 1 & 1 & 1 & 1 \\
\hline \multirow[t]{5}{*}{ Hymenochaetales } & Hymenochaetaceae & Hymenochaete & H. damicornis (Link) Lév. & 1 & 3 & 1 \\
\hline & & Phellinus & P. baccharidis (Pat.) Pat. & 1 & 1 & 1 \\
\hline & & Phellinus & P. fastuosus (Láv.) S. Ahmad & 1 & 7 & 2 \\
\hline & & Phellinus & P. gilvus (Schwein) Pat. & 1 & 1 & 1 \\
\hline & & Phellinus & P. rimosus (Berk.) Pilát & 1 & 1 & 1 \\
\hline \multirow[t]{22}{*}{ Polyporales } & Ganodermataceae & Amauroderma & sp. 1 & 1 & 1 & 3 \\
\hline & & Ganoderma & G. australe (Fr.) Pat. & 41 & 690 & 21 \\
\hline & Meripilaceae & Rigidoporus & R. biokoensis (Bres. ex Lloyd) Ryvarden & 4 & 89 & 13 \\
\hline & & Rigidoporus & R. lineatus (Pers.) Ryvarden & 11 & 209 & 17 \\
\hline & & Rigidoporus & R. microporus (Sw.) Overeem & 4 & 150 & 11 \\
\hline & Meruliaceae & Cymatoderma & sp. 1 & 1 & 38 & 5 \\
\hline & & Flaviporus & F. liebmannii (Fr.) Ginns & 2 & 4 & 1 \\
\hline & Phanerochaetaceae & Antrodiella & sp. 1 & 1 & 3 & 2 \\
\hline & & Inflatostereum & I. glabrum (Pat.) D.A. Reid & 2 & 64 & 2 \\
\hline & Polyporaceae & Echinochaete & E. brachypora (Mont.) Ryvarden & 1 & 72 & 9 \\
\hline & & Fomes & F. fasciatus (Sw.) Cooke & 2 & 5 & 2 \\
\hline & & Microporellus & M. obovatus (Jungh.) Ryvarden & 4 & 45 & 7 \\
\hline & & Nigroporus & N. vinosus (Berk.) Murril & 1 & 1 & 1 \\
\hline & & Perenniporia & P. inflexibilis (Berk.) Ryvarden & 1 & 1 & 1 \\
\hline & & Perenniporia & P. martia (Berk.) Ryvarden & 2 & 9 & 4 \\
\hline & & Polyporus & P. guianensis Mont. & 2 & 11 & 3 \\
\hline & & Favolus & F. tenuiculus P. Beauv. & 10 & 2163 & 32 \\
\hline & & Trametes & T. lactinea (Berk.) Sacc. & 1 & 9 & 3 \\
\hline & & Trametes & T. máxima (Mont.) A. David \& Rajchenb. & 1 & 7 & 2 \\
\hline & & Trametes & T. modesta (Kunze ex Fr.) Ryvarden & 2 & 26 & 3 \\
\hline & & Trametes & T. pavonia (Berk.) Fr. & 1 & 2 & 1 \\
\hline & & Trametes & sp. 1 & 1 & 4 & 2 \\
\hline Polyporales & & & Polyporales sp. 3 & 1 & 13 & 3 \\
\hline Polyporales & & & Polyporales sp. 4 & 1 & 51 & 6 \\
\hline Stereales & Stereaceae & & Stereaceae sp. 1 & 4 & 58 & 2 \\
\hline Tremellales & Tremellaceae & Tremella & T. fuciformis Berk. & 1 & 1 & 1 \\
\hline Xylariales & Xylariaceae & Xylaria & sp. 1 & 1 & 4 & 3 \\
\hline Total & & & & 159 & 5124 & \\
\hline
\end{tabular}



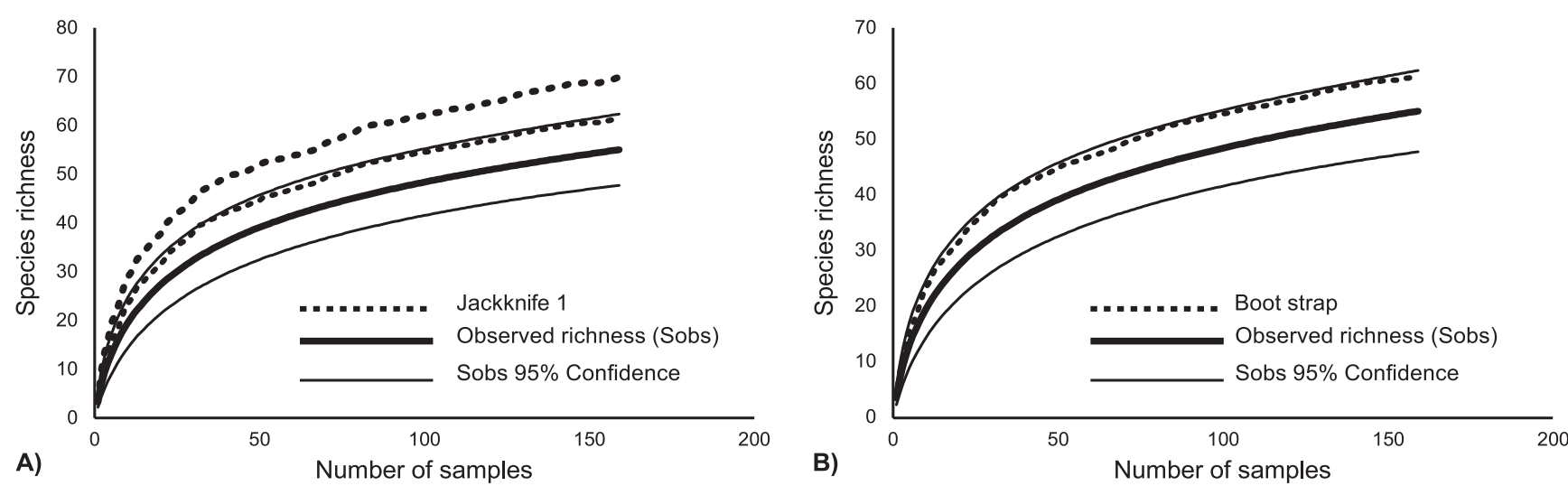

Figure 1. Species accumulation curves for the observed richness of the Drosophilidae guild from Caxiuanã National Forest Reserve relative to curves generated using Jackknife 1 (A) and Bootstrap (B) estimators.

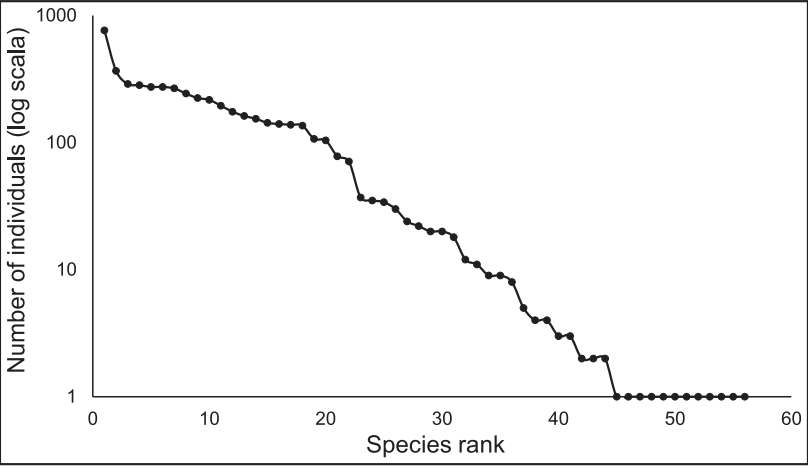

Figure 2. Ranking of the Log (N) abundance distributions of 55 mycophagous Drosophilidae species at Caxiuanã National Forest Reserve.

and were thus used to support the guild sampling effort. Jackknife 1 and Bootstrap estimators consider the incidence data (Magurran, 2011). Species richness curves and estimators were calculated (following 1,000 sample randomizations) using EstimateS 9.1.0 (Colwell, 2016).

The potential associations between Drosophilidae richness and fungal richness and/or abundance were evaluated using Spearman's correlation analysis. Evaluations were performed to investigate associations between the species richness of the two groups and between Drosophilidae richness and fungal abundance per sampling day. These analyses were performed using the Car package (Fox \& Weisberg, 2018) of R statistical software (R Development Core Team, 2018). To assess the species temporality, the relative frequency of fungal species was calculated as the ratio between the number of collections in which the species were observed and total number of collections (collections tree).

\section{RESULTS}

The samples consisted of 5,124 Drosophilidae specimens, which belongs to 55 species (including those identified as morphospecies), and 159 fruiting body samples, which belongs to 64 fungal species (including those identified as morphospecies) (Table 2). The collected species belongs to Zygothrica (26 species), Hirtodrosophila (19 species), Mycodrosophila (five species), Drosophila (four species) and Paraliodrosophila (one species) (Table 1). The fungal species were members of the orders Agaricales (eight families and 29 species), Polyporales (five families and 24 species), Hymenochaetales (one family and five species), Auriculariales, Cantharellales, Geastrales, Stereales, Tremellales and Xylariales (one species each) (Table 2).

The richness values estimated by Jackknife 1 and Bootstrap were 69 and 61 mycophagous Drosophilidae species, respectively, for the 159 fruiting bodies observed. The curves were ascending but showed signs of approaching an asymptote (Fig. 1).

The observed abundance distribution was the best fitting by Log-series model $\left(a=48.58, x^{2}=3.42, x=0.59\right.$, $p=0.94)$, which characterizes few very abundant species and many rare species (Fig. 2). The 22 most abundant species accounted for $93 \%$ of the individuals, while 22 out of the 55 species (40\%) were represented by less than 40 individuals, including 11 singletons (20\%). The most abundant species were Hirtodrosophila (SB13011) (15\% of all Drosophilidae), Zygothrica (SB14017) (7\%), Z. atriangula and Zygothrica (SB14024) (6\%). Z. zygia, Z. microerites, Z. atriangula, M. neoprojectans, Z. poeyi, Zygothrica (SB14016), Zygothrica (SB14038) and Drosophila (SB13009) displayed abundances representing $3 \%$ to $5 \%$ of all Drosophilidae (Table 1 ).

Drosophilidae richness and abundance correlated positively with fungal richness and abundance $(\rho=0.64$, $p=0.004$ and $\rho=0.73, p=0.004$, respectively).

Among the collected fungi, Favolus tenuiculus (Fig. 3a) had the highest abundance and richness of Drosophilidae visitors, with $42 \%$ of the drosophilid abundance and 32 species, followed by Ganoderma australe (Fig. 3b) with 13\% abundance and 21 species (Table 2). Furthermore, considering the relative frequency of fungal species as a measure of temporal availability, Ganoderma australe and Rigidoporus biokoensis were the most common species at a relative frequency of $100 \%$, and it was followed by seven species (Agaricales sp. 10, Gymnopus sp. 1, Gymnopus sp. 3, Favolus tenuiculus, Rigidoporus lineatus, Rigidoporus microporus and Trametes modesta), had a relative frequency of $60 \%$ and $86 \%$ of the collected fungi species were sampled in a single collection. 


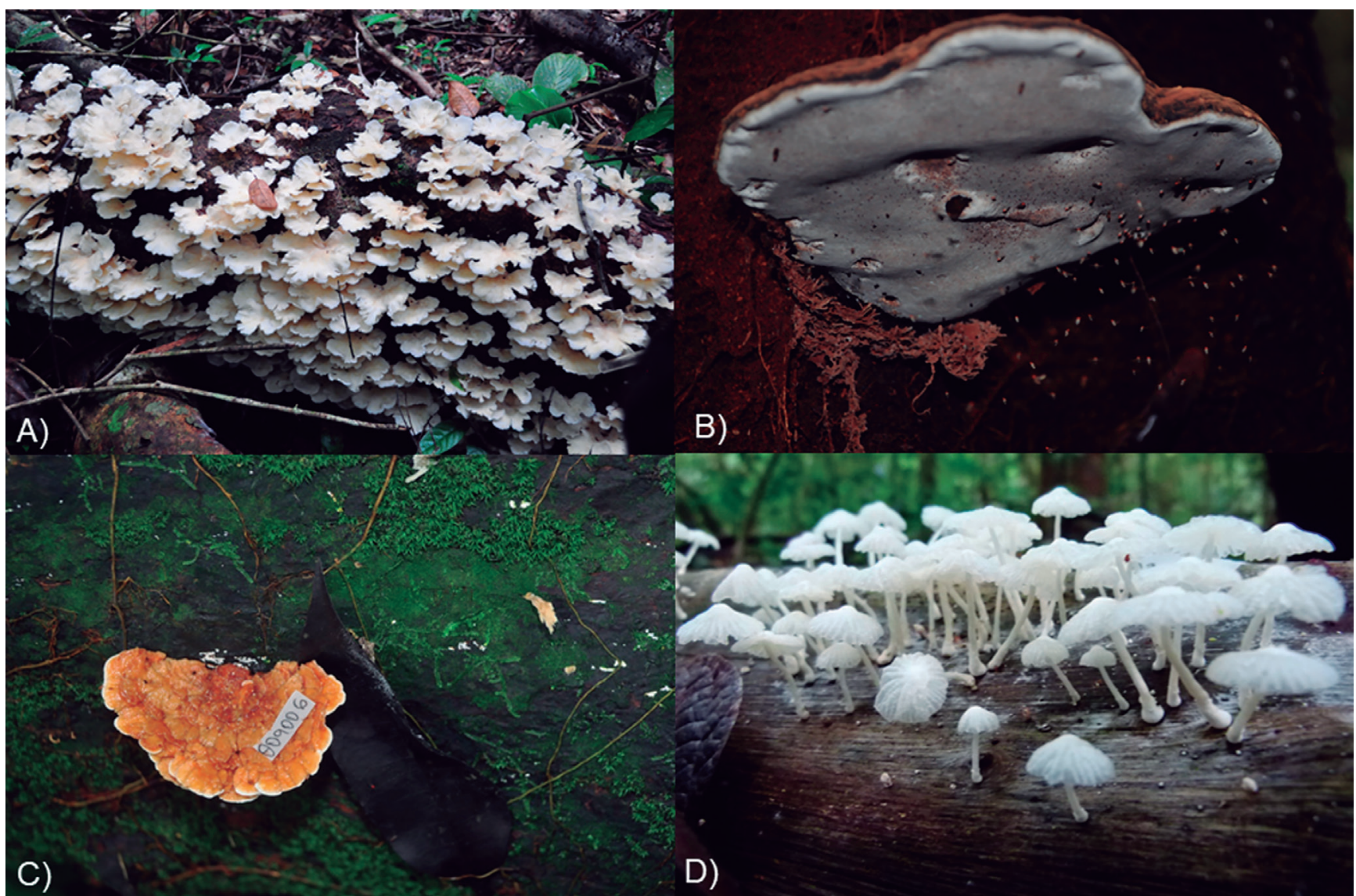

Figure 3. Examples of fungal species recorded for Caxiuanã National Forest Reserve: (A) Favolus tenuiculus, (B) Ganoderma australe, (C) Rigidoporus lineatus and (D) Marasmiellus sp. 4.

Out of the nine Mycodrosophila species found in the Neotropics, only five had been previously recorded in Brazil (Val et al., 1981; Junges et al., 2016). In this study, five Mycodrosophila species were observed (Table 1), including the first records of M. neoprojectans and M. pseudoprojectans to Brazil. Furthermore, our observation of $Z$. dimidiata was the first record of this species in Brazil, and $(56 \%)$ morphospecies of Drosophila Zygothrica and Hirtodrosophila might represent new species.

Among the collected Basidiomycetes, the order Polyporales displayed the highest richness of associated Drosophilidae, with 51 species, followed by Agaricales, with 31 species. Among families, Polyporaceae was the most visited by Drosophilidae, with 37 species and 2,350 visitors, followed by Meripilaceae and Omphalotaceae, with 23 species each and drosophilids abundances of 235 and 448, respectively.

\section{DISCUSSION}

The present study represents the largest survey of mycophagous Drosophilidae and their potential hosts in the Brazilian Amazon forest. The 55 species recorded at Caxiuanã National Forest Reserve represent 31\% of the Drosophilidae species known to date for the Amazon forest (Bächli, 2017). This study reaffirms that Neotropical mycophagous Drosophilidae are represented primarily by species that belong to the Zygothrica genus group (Grimaldi, 1987; Remsen \& O'Grady, 2002; Valer et al., 2016). The Drosophilidae richness value obtained in this study was greater than those reported for Australia (van Klinken \& Walter, 2001), Japan (Toda et al., 1999), the United States (Lacy, 1984) and the Pampas biome in Southern Brazil (Valer et al., 2016). The estimated richness data are consistent with previous studies (Burla, 1956; Grimaldi, 1987) that hypothesized that the mycophagous fauna might be richer in mature tropical forests.

The Log-Series Series model, which best described the mycophagous Drosophilidae abundance, indicates a guild structured by species dominance in resource utilization, predicts extremely unbalanced abundances among taxa (McGill et al., 2007; McGill, 2011) and identifies the dominant species.

Recurrent records of Hirtodrosophila, Mycodrosophila, Paraliodrosophila and Zygothrica species in macroscopic fungi confirm mycophagy in these genera (Grimaldi, 1987; Val \& Kaneshiro, 1988; Courtney et al., 1990; Valer et al., 2016), as well as their affinity for forest environments, as suggested by Spieth (1987).

The world's records of $M$. neoprojectans were restricted to Central America and Northern South America (Val et al., 1981), with records in Colombia (Bächli, 2017) that are now expanded to Brazil. This species abundance was proportionally high in two fungal species ( $F$. tenuiculus and $G$. australe), but the species was also observed in 21 other fungi, showing host versatility. Mycodrosophila pseudoprojectans, which also represents a new record for 
Brazil, occurs as well in Central America and Northern South America, Colombia and Peru (Bächli, 2017). In this study, M. pseudoprojectans exhibited high abundance in three fungal species (G. australe, Rigidoporus microporus and F. tenuiculus) and occurred in seven other host species, demonstrating polyphagy.

Our observation of M. brunnescens in this study is the first since 1952, when the first specimen was collected by Theodosius Dobzhansky in the city of Belém in Pará State, Brazil, although the substrate was not mentioned in that study (Wheeler \& Takada, 1963). In the present study, two specimens were recorded, one specimen found in $R$. lineatus and the other found in G. australe. This low occurrence suggests that both species are rare and may associate with another substrate that was not recorded in this study.

Another new occurrence for Brazil was a single Z. dimidiata specimen found in F. tenuiculus. This species was previously recorded in Peru (Wheeler, 1970). In addition, 13 species of the genus Zygothrica, three of the genus Drosophila and 15 of the genus Hirtodrosophila are probably new species.

These results indicate that Drosophilidae that visit fungi in the Amazon forest are represented by species that belong to genera of known mycophagous habits (Throckmorton, 1975; Grimaldi, 1987; Remsen \& O'Grady, 2002). This study highlights species of the Zygothrica genus group, confirming the hypothesis that genera in this group exhibit mycophagous habits in the Neotropics (Grimaldi, 1990; Remsen \& O'Grady, 2002; Valer et al., 2016). Moreover, as shown in the results, these genera are more representative in the Amazon biome.

Hirtodrosophila dominated the guild in a fly emergence dataset from the Pampas biome (Valer et al., 2016). However, in the present study, this genus was the most generalist genus with respect to potential hosts, in contrast to observations made by Valer et al. (2016). Fly emergence studies for the Amazon biome are needed to corroborate the potential generalist character of Hirtodrosophila.

Among the 36 fungal genera recorded, 28 were visited by Hirtodrosophila, while Mycodrosophila, Zygothrica and Drosophila visited 22, 20 and 18 host genera, respectively. In this study and in a study performed by Grimaldi (1987), Zygothrica did not occur in fungi of the genera Pleurotus. Moreover, Zygothrica were not observed in any other genera of the Pleurotaceae. In the Holarctic region Hirtodrosophila is commonly recorded in Collybia (Yamashita \& Hijii, 2007), in this study we recorded two species in Collybia aurea.

The family Polyporaceae attracted the highest diversity of flies. These results are in agreement with previous studies that suggested that this family is one of the most utilized by mycophagous Drosophilidae (Grimaldi, 1987; Lacy, 1984; Gottschalk et al., 2009). Polyporaceae displays high species richness in the studied area (Sotão et al., 2009). The Drosophilidae preference for Polyporaceae species may be due to the succulent basidiocarp of these fungi, which facilitates ovipositor penetration and allows more larval mobility, as well as representatives of the family do not present toxic compounds, which can favour the selection by Drosophilidae (Lacy, 1984). Furthermore, the fruiting bodies of these fungi can last for months, allowing the full development of the larvae, while the fruiting bodies of Agaricales are ephemeral, lasting only days or even a few hours (Gugliota \& Capelari, 1998).

The availability of fungal species (measured by number of samples and relative frequency) contribute to increase the abundance and species richness of drosophilids visiting the fungi. In fact, Valadão et al. (2010) and Döge et al. (2015) observed that the availability of resources is the main factor affecting the size of the Drosophilidae populations. We observed that the highest drosophilid richness and abundance were recorded during the $3^{\text {rd }}$ expedition (May, 2014), when F. tenuiculus was observed to have high fly abundances. The preference of flies for this species with fleshy basidiocarp could be due to the fungal quality (Courtney et al., 1990) and with large fruiting bodies in the substrates (Fig. 3a). However, given that F. tenuiculus is ephemeral, heterogeneously distributed throughout the Caxiuanã National Forest Reserve and highly abundant at certain periods within the wet season (Medeiros et al., 2015), it is not possible to state that this species is responsible for maintaining guild richness. It is possible that the high attractiveness of $F$. tenuiculus is the result of both substrate quality and the influence of rainfall. In fact, Valadão et al. (2010) and Carvalho (2014) observed that fruit substrates were more attractive to flies during high rainfall periods.

Finally, the fungal richness and abundance at Caxiuanã National Forest Reserve were the factors that determined the diversity of mycophagous Drosophilidae. This observation is consistent with the predicted outcome of a strategy that includes the utilization of a temporally and spatially unpredictable resource. Due to such unpredictability, the evolution of specialization mechanisms is unlikely (Kimura et al., 1978; Jaenike, 1978). However, considering that fruiting bodies are nearly absent during periods of lower rainfall, the strategies employed by these species to survive the lack of resources remains unknown.

\section{ACKNOWLEDGEMENTS}

We are grateful to Cleumar Lopez, Cleidimar Araújo de Sousa and Flávio Vieira Vaz for helping in the fieldwork. Special thanks to Felipe G.B. Pinheiro for help in the identification of fungi; and Marcos de S. Fialho for improving the text. Scholarships, permission to collect specimens and logistical support were provided by Conselho Nacional de Desenvolvimento Científico e Tecnológico (RSB, \#130023/2013-2; CJBC, \#309873/2016-9; FW, \#307947/2017-3), Instituto Chico Mendes de Conservação da Biodiversidade (permit \#39992-1), Programa de Pós-Graduação de Entomologia da Universidade Federal do Paraná, Programa de Pesquisa Ecológica de Longa Duração (\#441224/2016-4), Estação Científica Ferreira Penna and Museu Paraense Emílio Goeldi. 


\section{REFERENCES}

Ackerman, J.K. \& Shenefelt, R.D. 1973. Organisms, especially insects, associated with wood rotting higher fungi (Basidiomycetes) in Wisconsin forests. The Wisconsin Academy of Sciences, Arts and Letters, 61: 185-206.

Bächli, G. 2017. Taxodros: The database on taxonomy of Drosophilidae. http:// www.taxodros.uzh.ch. Access in: 28/07/2017.

Bock, I.R. \& Parsons, P.A. 1978. Australian endemic Drosophilidae V. Queensland rainforest species associated with fungi with descriptions of six new species and a redescription of $D$. pectipennis Kertész. Australian Journal of Zoology, 26: 331-347.

Brncic, D. 1957. Las especies chilenas de Drosophilidae. Santiago, Universidad de Chile. 136p. (Colección de Monografías Biológicas de la Universidad de Chile, 8).

Burla, H. 1956. Die Drosophilidengattung Zygothrica und ihre beziehung zur Drosophila-untergattung Hirtodrosophila. Mitteilungen aus dem Zoologischen Museum in Berlin, 32: 189-321.

Burla, H. \& Bächli, G. 1968. Beitrag zur Kenntnis der schweizerischen Dipteren, insbesondere Drosophila-Arten, die sich in Fruchtkörpern von Hutpilzen entwickeln. Vierteljahrsschrift der Naturforschenden Gesellschaft in Zurich, 113: 311-336.

Buxton, P.A. 1954. British Diptera associated with fungi. 2 - Diptera bred from myxomycetes. Physiological Entomology, 29: 163-171.

Buxton, P.A. 1960. British Diptera associated with fungi III. Flies of all families reared from about 150 species of fungi. Entomologist's Monthly Magazine, 96: 61-94.

Carvalho, A.L.B. 2014. Variação sazonal na estrutura de comunidade de Drosofilídeos (Insecta; Diptera) em função dos elementos climáticos em remanescentes de floresta. (Master Dissertation). Belém, Museu Paraense Emílio Goeldi, Universidade Federal do Pará.

Colwell, R.K. 2016. Estimates: statistical estimation of species richness and shared species from samples. Versão 9.1.0. Access in: 28/11/2017.

Cordeiro, A.R. 1952. Drosophila (Hirtodrosophila) caxiensis, a new species of fungus-feeding fly from Brasil. Dusenia, 3: 303-308.

Costa, A.C.L.; Almeida, S.S.; Carvalho, C.R.; Meir, P.; Mahi, Y.; Costa, R.F.; SilvaJúnior, J.A.; Costa, M.C.; Tanaka, B.T.; Fisher, R.A.; Sotta, E.D.; Oliveira, L.L.; Gonçalves, P.H.L.; Braga, A.P. \& Barreto, P.N. 2009. Clima. In: Lisboa, P.L.B. (Ed.). Caxiuanã - Desafios Para a Conservação de uma Floresta Nacional na Amazônia. Belém, Museu Paraense Emílio Goeldi. p. 45-90.

Courtney, S.P.; Kibota, T.T. \& Singleton, T.A. 1990. Ecology of mushroomfeeding Drosophilidae. Advances in Ecological Research, 20: 225-274.

Coutin, R. 1982. Insectes et champignons. Cahier de Liaison, 16: 3-12.

Diamond, J. 1986. Overview: Laboratory experiments, field experiments, and natural experiments. In: Diamond, J. Case, T.J. (Eds.). Community Ecology. New York, Harper \& Row Publishers. p. 3-22.

Döge, J.S.; de Oliveira, H.V. \& Tidon, R. 2015. Rapid response to abiotic and biotic factors controls population growth of two invasive drosophilids (Diptera) in the Brazilian Savanna. Biological Invasions, 17: 2461-2474.

Fauth, J.E.; Bernardo, J.; Camara, M.; Resetarits, W.J.; van Buskirk, J. \& Mccollum, S.A. 1996. Simplifying the jargon of community ecology: a conceptual approach. The American Naturalist, 147: 282-286.

Fidalgo, 0. \& Bononi, V.L. 1989. Guia de coleta, preservação e herborização de material Botânico. São Paulo, Instituto de Botânica. 62p. (Manual n. 4)

Fox, J. Jr. \& Weisberg, S. 2018. An R Companion to Applied Regression. 2. ed. Thousand Oaks, Sage Publ.

Frota-Pessoa, 0. 1945. Sobre o subgênero "Hirtodrosophila", com descrição de uma nova espécie (Diptera, Drosophilidae, Drosophila). Revista Brasileira de Biologia, 5: 469-483.

Frota-Pessoa, 0. 1951. Drosophila (Hirtodrosophila) magnarcus n. sp. (Diptera, Drosophilidae). Revista Brasileira de Biologia, 11: 407-411.
Furtado, J.S. 1981. Taxonomy of Amauroderma (Basidiomycetes, Polyporaceae). Memoirs of the New York Botanical Garden, 34: 1-109.

Gottschalk, M.S.; Bizzo L.; Döge, J.S.; Profes, M.S.; Hofmann, P.R.P. \& Valente, V.L.S. 2009. Drosophilidae (Diptera) associated to fungi: differential use of resources in anthropic and Atlantic Rain Forest areas. Iheringia, Série Zoologia, 99: 442-448.

Gottschalk, M.S.; Hofmann, P.R.P. \& Valente, V.L.S. 2008. Diptera, Drosophilidae: historical occurrence in Brazil. Check List, 4: 485-518.

Grimaldi, D.A. 1987. Phylogenetics and taxonomy of Zygothrica (Diptera: Drosophilidae). Bulletin of the American Museum of Natural History, 186: 103-268.

Grimaldi, D.A. 1990. A phylogenetic, revised classification of genera in the Drosophilidae (Diptera). Bulletin of the American Museum of Natural History, 197: 1-139.

Grimaldi, D.A.; James, A.C. \& Jaenike, J. 1992. Systematics and modes of reproductive isolation in the Holarctic Drosophila testacea species group (Diptera: Drosophilidae). Annals of the Entomological Society of America, 85: 671-685.

Gugliota, A.M. \& Capelari, M. 1998. Taxonomia de Basidiomicetos. In: Bononi, V.L.R. \& Grandi, R.A.P. (Eds.). Zigomicetos, Basidiomicetos e Deuteromicetos: noções básicas de taxonomia e aplicações biotecnológicas. São Paulo, Instituto de Botânica. p. 68-105.

Hammer, Ø.; Harper, D.A.T. \& Ryan, P.D. 2001. PAST: Palaeontological statistics software for education and data analysis. Palaeontologia Electronica, 4: 1-9. http://palaeo-electronica.org/2001 1/past/issue1 01.htm. Access in: $15 / 08 / 2017$.

Hanski, I. 1989. Fungivory: fungi, insects and ecology. In: Collins, N.M.; Hammond, P.M. \& Webber, J.B. (Eds.). Insect-Fungus Interaction. Wilding. Insect-Fungus Interaction. London, Academic Press. p. 25-68.

Heard, S.B. 1998. Resource patch density and larval aggregation in mushroom-breeding flies. Oikos, 81: 187-195.

Heed, W.B. 1957. Ecological and distributional notes on the Drosophilidae (Diptera) of El Salvador. In: Wheeler, M.R. (Ed.). Studies in the genetics of Drosophila. Texas, University of Texas Publication. p. 62-78.

Hendel, F. 1936. Ergebnisse einer zoologischen Sammelreise nach Brazilien insbesondere in das Amazonasgebiet, ausgefuhrt von Dr. H. Zerny. X. Teil. Diptera. Muscidae acalyptratae (excl. Chloropidae). Annalen des Naturhistorischen Museums in Wien, 47: 61-106.

Hosaka, K. \& Uno, K. 2012. A preliminary Survey on Larval Diversity in Mushroom Fruit Bodies. Bulletin of the National Museum of Nature and Science Series B, Botany, 38: 77-85.

Jaenike, J. 1978. Host selection by mycophagous Drosophila. Ecology, 59: 1286-1288.

Junges, J.; Gottschalk, M.S.; Loreto, E.L.S. \& Robe, L.J. 2016. Two new species of Mycodrosophila (Diptera, Drosophilidae) proposed by molecular and morphological approaches, with a key to American species. Revista Brasileira de Entomologia, 60: 30-39. DOI

Kadowaki, K. 2010. Species coexistence patterns in a mycophagous insect community inhabiting the wood-decaying bracket fungus Cryptoporus volvatus (Polyporaceae: Basidiomycota). European Journal of Entomology, 107: 89-99.

Kaneshiro, K.Y. 1969. A study of the relationships of Hawaiian Drosophila species based on external male genitalia. University of Texas Publications, 6918: 55-70

Kimura, M.T. 1976. Drosophila survey of Hokkaido, XXXII. A field survey of fungus preferences of Drosophilid flies in Sapporo. Journal of the Faculty of Science Hokkaido University, 20: 288-298.

Kimura, M.T.; Beppu, K.; Ichijo, N. \& Toda, M.J. 1978. Bionomics of Drosophilidae (Diptera) in Hokkaido. II. Drosophila testacea. Kontyû, 46: 585-595. 
Kirk, P.M.; Cannon, P.F.; David, J.C.;Minter, D.W. \& Stalpers, J.A. 2008. Ainsworth \& Bisby's Dictionary of the Fungi. 8. ed. Wallingford, CAB International.

Krebs, C.J. 1999. Ecological methodology. Vancouver, CA, University of British Columbia.

Lacy, R.C. 1984. Predictability, toxicity, and trophic niche breadth in fungusfeeding Drosophilidae (Diptera). Ecological Entomology, 9: 43-54.

Lisboa, P.L.B. 2007. A Estação Científica Ferreira Penna/ECFPn (1993-2000). In: Lisboa, P.L.B. (Ed.). Caxiuanã: populações tradicionais, meio físico e diversidade biológica. Belém, Museu Paraense Emílio Goeldi. p. 35-55.

Magurran, A.E. 2011. Medindo a diversidade biológica. Curitiba, Editora UFPR.

Martin, M.M. 1979. Biochemical implications of insect mycophagy. Biological Reviews, 54: 1-21.

Mcgill, B.J. 2011. Species abundance distributions. In: Magurran, A.E. \& McGill, B.J. (Eds.). Biological diversity: Frontiers in measurement and assessment. New York, Oxford University Press. p. 105-122.

Mcgill, B.J.; Etienne, R.S.; Gray, J.S.; Alonso, D.; Anderson, M.J.; Benecha, H.K.; Dornelas, B.; Enquist, B.J.; Green, J.L.; Hurlbert, A.H.; Magurran, A.E.; Marquet, P.A.; Maurer, B.A.; Ostling, A.; Soykan, C.U.; Ugland, K.I. $\&$ White, E.P. 2007. Species abundance distributions: moving beyond single prediction theories to integration within an ecological framework. Ecological Letters, 10: 339-1015. D0I

Medeiros, P.S.; Cattanio, J.H. \& Sotão, H.M.P. 2015. Riqueza e relação dos fungos poróides lignolíticos (Agaricomycetes) com 0 substrato em floresta da Amazônia brasileira. Boletim do Museu Paraense Emílio Goeldi, Série Ciências Naturais, 10: 423-436.

Mourão, C.A.; Gallo, A.J. \& Bicudo, H.E.M.C. 1965. Sôbre a sistemática de Drosophila no Brasil, com descrição de $D$. mendeli sp. n. e "Relação de espécies brasileiras do gênero Drosophila". Ciência e Cultura, 17: 577-586.

Mourão, C.A.; Gallo, A.J. \& Bicudo, H.E.M.C. 1967. Drosophila morgani, nova espécie brasileira (Drosophilidae, Diptera). Papéis Avulsos de Zoologia, 20: 159-164.

Oliveira, L.L.; Costa, R.F.; Costa, A.C.L.; Souza, F.A.Z. \& Braga, A.P. 2008. Modelagem da interceptação na Floresta Nacional de Caxiuanã, no leste da Amazônia. Revista Brasileira de Metereologia, 23: 318-326. D0I

Parsons, P. 1977. Lek behaviour in Drosophila (Hirtodrosophila) polypori Malloch an Australian rainforest species. Evolution, 31: 223-225.

Pavan, C.; Dobzhansky, T. \& Burla, H. 1950. Diurnal behavior of some neotropical species of Drosophila. Ecology, 31: 36-43.

Pielou, E.C. 1975. Ecological diversity. New York, John Wiley.

Powell, J.R. 1997. Progress and prospects in evolutionary biology: the Drosophila model. New York, Oxford University Press.

R Development Core Team. 2018. R: A Language and environment for statistical computing. Vienna, R Foundation for Statistical Computing.

Remsen, J. \& O'grady, P.M. 2002. Phylogeny of Drosophilinae (Diptera: Drosophilidae), with comments on combined analysis and character support. Molecular Phylogenetic and Evolution, 24: 249-264.

Root, R.B. 1967. The niche exploitation pattern of the Blue-Gray Gnatcatcher. Ecological Monographs, 37(4): 317-350.

Roque, F. \& Tidon, R. 2008. Eight new records of drosophilids (Insecta; Diptera) in the Brazilian savanna. Drosophila Information Service, 91: 94-97.

Roque, F.; Figueiredo, R. \& Tidon, R. 2006. Nine new records of drosophilids in the Brazilian savanna. Drosophila Information Service, 89: 14-17.

Ryvarden, L. 1991. Genera of Polypores: nomenclature and taxonomy. Synopsis Fungorum, 5: 1-373.

Ryvarden, L. 2004. Neotropical Polypores. Part 1. Synopsis Fungorum, 19: $1-227$.

Ryvarden, L. \& Johansen, I. 1980. A preliminary polypore flora of East Africa. 0slo, Fungiflora.

Shorrocks, B. \& Charlesworth, P. 1980. The distribution and abundance of the British fungal-breeding Drosophila. Ecological Entomology, 5: 61-78.
Shorrocks, B. \& Charlesworth, P. 1982. A field study of the association between the stinkhorn Phallus impudicus Pers. and the British fungal-breeding Drosophila. Biological Journal of the Linnean Society, 17: 301-318.

Smith, E.P. \& van Belle, G. 1984. Nonparametric estimation of species richness. Biometrics, 40: 119-129.

Sotão, H.M.P.; Gibertoni, T.B.; Maziero, R.; Baseia, I.G.; Medeiros, P.S.; MartinsJúnior, A.S. \& Capelari, M. 2009. Fungos macroscópicos da Floresta Nacional de Caxiuanã: Basidiomycota (Agaricomycets). In: Lisboa, P.L.B. (Eds.). Caxiuanã: Desafios para Conservação de uma Floresta Nacional na Amazônia. Belém, Museu Paraense Emílio Goeldi. p. 383-396.

Spieth, H.T. 1987. The Drosophila fauna of a native California forest (Diptera: Drosophilidae). Pan-Pacific Entomologist, 63: 247-255.

Sturtevant, A.H. 1920. The dipterous genus Zygothrica of Wiedemann. Proceedings of the United States National Museum, 58: 155-158.

Sturtevant, A.H. 1921. The North American species of Drosophila. Washington, Carnegie Institution of Washington Publication, 301: 1-150.

Sugihara, G. 1980. Minimal community structure: an explanation of species abundance patterns. The American Naturalist, 116: 770-787.

Takahashi, K.H.; Tuno, N. \& Kagaya, T. 2005. Abundance of mycophagous arthropods present on different species of fungi relation to resource abundance at different spatial scales. European Journal of Entomology, 102: 39-46.

Teixeira, A.R. 1995. Método para estudo das hifas do basidiocarpo de fungos poliporáceos. São Paulo, Instituto de Botânica. (Manual n. 6)

Throckmorton, L.H. 1975. The phylogeny, ecology and geography of Drosophila. In: King, R.C. (Ed.). Handbook of genetics. New York, Plenum Press. p. 421-469.

Toda, M.J.; Kimura, M.T. \& Tuno, N. 1999. Coexistence mechanisms of mycophagous drosophilids on multispecies fungal hosts: Aggregation and resource partitioning. Journal of Animal Ecology, 68: 794-803.

Val, F.C.; Vilela, C.R. \& Marques, M.D. 1981. Drosophilidae of the Neotropical region. In: Ashburner M. Carson H.L. Thompson Jr., J.N. (Eds.). The genetics and biology of Drosophila. London, Academic Press. p. 123-168.

Val, F.C. \& Kaneshiro, K.Y. 1988. Drosophilidae (Diptera) from the Estação Biológica de Boracéia, on the coastal range of the state of São Paulo, Brazil: geographical distribution. In: Vanzolini, P.E. \& Heyer, W.R. (Eds.). Proceedings of a workshop on Neotropical distribution patterns. Rio de Janeiro, Academia Brasileira de Ciências. p. 189-203.

Valadão, H.; Hay, J.D.V. \& Tidon, R. 2010. Temporal dynamics and resource availability for Drosophilid fruit flies (Insecta, Diptera) in a gallery forest in the Brazilian Savanna. International Journal of Ecology, 2010(Suppl.): 152437. DOI

Valer, F.B.; Bernardi, E.; Mendes, M.F.; Blauth, M.L. \& Gottschalk, M.S. 2016. Diversity and associations between Drosophilidae (Diptera) species and Basidiomycetes in a Neotropical forest. Anais da Academia Brasileira de Ciências, 88: 1-14. D0I

van Klinken, R.D. \& Walter, G.H. 2001. Larval hosts of Australian Drosophilidae (Diptera): A field survey in subtropical and tropical Australia. Australian Journal of Entomology, 40: 163-179.

Vilela, C.R. \& Bächli, G. 1990. Taxonomic studies on Neotropical species of seven genera of Drosophilidae (Diptera). Mitteilungen der Schweizerische Entomologischen Gesellschaft, 63: 1-332.

Vilela, C.R. \& Bächli, G. 2004. On the identities of nine Neotropical species of Hirtodrosophila (Diptera, Drosophilidae). Mitteilungen der Schweizerische Entomologischen Gesellschaft, 77: 161-195

Vilela, C.R. \& Bächli, G. 2007. Revision of the Neotropical genus Paraliodrosophila (Diptera, Drosophilidae). Mitteilungen der Schweizerische Entomologischen Gesellschaft, 80: 291-317.

Wertheim, B.; Sevenster, J.G.; Eijs, I.E.M. \& Van Alphen, J.J.M. 2000. Species diversity in a mycophagous insect community: the case of spatial 
aggregation vs. resource partitioning. Journal of Animal Ecology, 69: 335-351.

Wheeler, M.R. 1970. A catalogue of the Diptera of the Americas South of the United States: Family Drosophilidae. São Paulo, Museu de Zoologia, Universidade de São Paulo.

Wheeler, M.R. \& Kambysellis, M.P. 1966. Notes on the Drosophilidae (Diptera) of Samoa. University of Texas Publications, 6615: 533-565.

Wheeler, M.R. \& Takada, H. 1963. A Revision of the American Species of Mycodrosophila (Diptera; Drosophilidae). Annals of the Entomolology Society of America, 36: 391-399.
Worthen, W.B. 1989. Effects of resource density on mycophagous fly dispersal and community structure. Oikos, 54: 145-153.

Yamashita, S. \& Hijii, N. 2003. Effects of mushroom size on the structure of a mycophagous arthropod community: Comparison between infracommunities with different types of resource utilization. Ecological Research, 18: 131-143.

Yamashita, S.\& Hijii, N. 2007. The role of fungal taxa and developmental stage of mushrooms in determining the composition of the mycophagous insect community in a Japanese forest. European Journal of Entomology, 104: $225-233$ 